\title{
Safety and Durability Analysis of Structural Works in Civil Engineering
}

\author{
Yu Zhang ${ }^{1}$ \\ Xijing University, 710123, Xi'an, China \\ e-mail:176288793@qq.com \\ Shidan $\mathrm{He}^{3}$ \\ Xijing University, 710123, Xi'an, China \\ e-mail:1546653654@qq.com
}

\author{
Xiaofang $\mathrm{Li}^{2}$ \\ Xijing University, 710123, Xi'an, China \\ e-mail: lixiaofangxijing@126.com
}

\begin{abstract}
Based on the study of bitter and tremendous costs paid in managing and maintaining structure works in Civil engineering, factors that influence the safety and durability of Civil engineering and that cause the Civil engineering accidents are analyzed. In this paper, three indispensable measures to improve the safety and durability of structure works in Civil engineering are suggested: firstly, Reasonable setting the safety level of civil engineering design. The basis of the reasonable set of civil Safety level of structural engineering design, which can effectively avoid the risk of engineering. secondly, Pay attention to the safety and durability of civil engineering structures. We need to pay attention to the safety and durability of civil engineering structures, and strengthen the regular support Nursing management. The third , Improve the safety and durability of civil engineering design standards .According to the concrete conditions of the project, the durability of civil engineering structure is reasonably designed, clear the engineering design and the use of life, to protect the safety and durability of civil engineering structure better.
\end{abstract}

Keywords- structure works of civil engineering; standard; safety level set up; safety; durability

\section{INTRODUCTION}

The concept of sustainability was first defined by the Brundtland Commission of the United Nations in 1987 as the "a development that meets the needs of the present without compromising the ability of future generations to meet their own needs." ${ }^{[1]}$ It is known that accidents at civil buildings depend on human errors in $80 \%$ of all accidents $[2,3]$. The source of faults is an insufficient level of knowledge, lack of experience, inaccurate documents, violation of process discipline and negligence ${ }^{[4,5,6]}$. Bad mistakes at work execution can lead to critical defects affecting the possibility to use products for their designated purpose, their reliability and safety ${ }^{[6,7] \text {. }}$

\section{A. Significance of research}

Maintaining the Integrity of the Specifications Structural safety is the ability to prevent the collapse of the structure. Quality is the most important index of structural engineering. It not only depends on the structure of the design and construction standards, but also on the structure of the right use (maintenance, testing), and these are the civil engineering regulations and technical standards (specifications, procedures, regulations, etc.) To set it reasonable and transport for structural engineering design, the structure of the main body's safety. Now the bearing capacity of structure and the security of structure, depends on several aspects of the overall solid structure, such as the durability of the structure and the structure safety ${ }^{[8]}$.

\section{B. Domestic Research Status and reasons}

For a long time, the main component of the civil structure of our country is concrete, the safety and durability of the concrete structure directly determines the quality of the civil engineering construction. From the current development situation of civil engineering structures, the safety and durability of the lecturer is a long time in the main direction of civil engineering analysis. The earliest safety and durability concept on the civil engineering structure was proposed in the seventy 's of last century. Part of the developed countries were developed exists obvious damage of the original infrastructure. Survey and analysis shows that the eighty's civil engineering in our country were in the use of 25-30 years, most of the construction of our country appeared big or small quality problems. Where the bridge port ditch and other infrastructure damage. The investigation has caused all circles concern about the safety and durability of civil engineering structures.

\section{Analysis and improving measures}

In civil engineering, there is a problem of low safety and durability. The main reasons through a large number of survey analysis and research, were summarized as follows:

The first, Some developers pursuit construction progress seriously, and lack of necessary construction maintenance period .With the rapid development of economy, the process of civil engineering construction is required to accelerate the construction process and shorten the construction period, which eventually lead to concrete structure's safety and durability of the continuous reduction because of the lack of minimum time limit. In addition, construction formwork randomly not in accordance or under the premise of the requirements. In the process of the construction, the concrete structure quality of the concrete structure has been decreased.

Second, construction personnel lack of special training, quality and unreasonable during construction. With the acceleration of social processes continuously, leading to the shortage of construction personnel. A large number of migrant workers into the city, become the construction of civil engineering construction. Most of 
them have low cultural quality and lack of professional skills training. The process of operational error during the implementation of civil engineering structure are seriously. to a certain extent, affect the safety and durability of civil engineering structure.

Third, civil engineering operators lack of innovation and research awareness due to the rules and regulations. China has a large number of laws and regulations for the construction of civil engineering construction, which lead to operators unnecessary ideological restraint in the operation and construction of the construction. Due to the personnel of construction lack of innovation and research consciousness, indirectly led to the construction of civil engineering quality and safety problems cannot be resolved in the long-term.

Fourth, acid rain and other natural disasters increased the damage of civil engineering structures

China has attached importance to economic growth in a long time and ignored the protection of environmental. Which resulting in deteriorating environment, natural disasters. Acid rain and waste gas play an important role in affecting the safety and durability of civil engineering structures. In our country operators pays more attention to the concrete structure itself and the architectural design in construction civil engineering. In China people neglect the interference of the objective factors of the environment during the construction process, which leads to the problem of civil engineering structure obviously ${ }^{[9]}$.

To solve the above problems, some methods were put forwarded.

First, pay attention to the safety and durability of civil engineering structures. It is necessary to pay more attention to the safety and durability of civil engineering, and to ensure the safety and durability of civil engineering structure, which is to strengthen and ensure the safety and durability of civil engineering. The so-called civil structure of the durability of the structure is to resist the external factors of the long-term impact of the safety hazards. Due to the ability of these natural factors is unavoidable, so that the durability of civil structure of this kind of durability security should be pay more attention. But to our said is that because our country is vast, environmental differences we found that China's concern in this area is not enough. So that we must draw lessons from each accident, attention to the prevention and improvement of durability of the safety of the project. It is also very important performance to responsible for other project.

Second, setting the safety level of civil engineering design reasonable. The design of civil engineering, is not only to consider the project risk, but also should consider the impact on social stability, economic development, resource utilization. On this basis, set up the safety level of civil engineering design reasonable. So as to avoid the risk of engineering effectively. Set reasonable safety level of civil engineering structure design, mainly including the following aspects: to improve the anti disaster ability of civil structural engineering, such as earthquakes, typhoons, fires and other; enhance firm structure performance and avoid man-made damage to the structure cause the safe hidden trouble; reasonable forecast the possible of load change, and prepared measures to deal with it. In order to enhance the resilience increase structural component's safety reserves and the value of bearing capacity of structure load standard suitably ${ }^{[10]}$. At present, the quality of concrete is too single, can not from all directions to inspect the quality of concrete, the strength of the standard as a measure of concrete quality standards, resulting in cement fineness increased, the proportion of mineral composition is unreasonable, the strength test of cement quality is not the highest, which is not conducive to the uniformity of the overall product quality.

Thirdly, improve the safety and durability of civil engineering design standards. At present, the safety and durability design standards in our country's civil engineering are not perfect. There are still exist many problems, according to the specific circumstances of the project, the reasonable design of civil engineering structure, and the durability of the engineering design. To better protect the safety and durability of civil engineering structure the durability design of civil engineering structures are as follows: we should invest and research construction site environment detailedly; design of civil structure and its components reasonable; determine material durability index, requirements and construction quality, process control requirements reasonable etc. Civil engineering design and use of life refers to the engineering applicability and safety performance. To meet the minimum age of design requirements, with the intention of the owners, the design experience, the relevant laws and regulations were needed.

What's more in our country the reliability design methods, experience and problems of the building structure design specification uses are worth summarizing. Reliability methods for different types of the structure of the prerequisite. The difficulty it is also different due to types of the structure. Recommend that the relevant departments in the promotion of all kinds of design specifications should be widely used to collect all kinds of views, seeking truth from facts, stable and cautious treatment. 


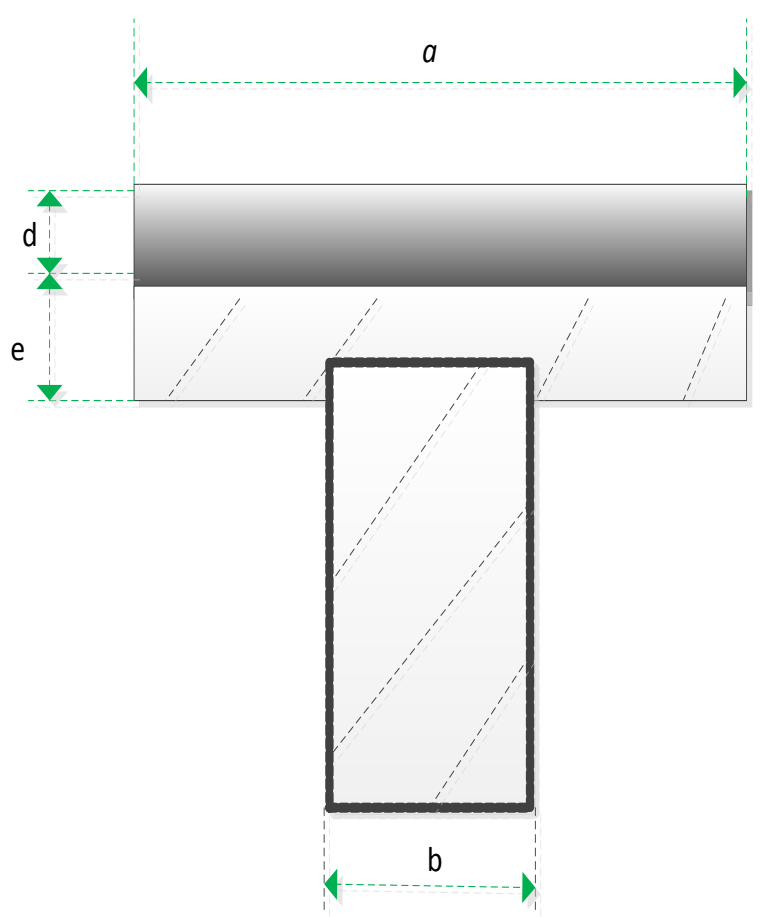

Figure 1. Cross sectio
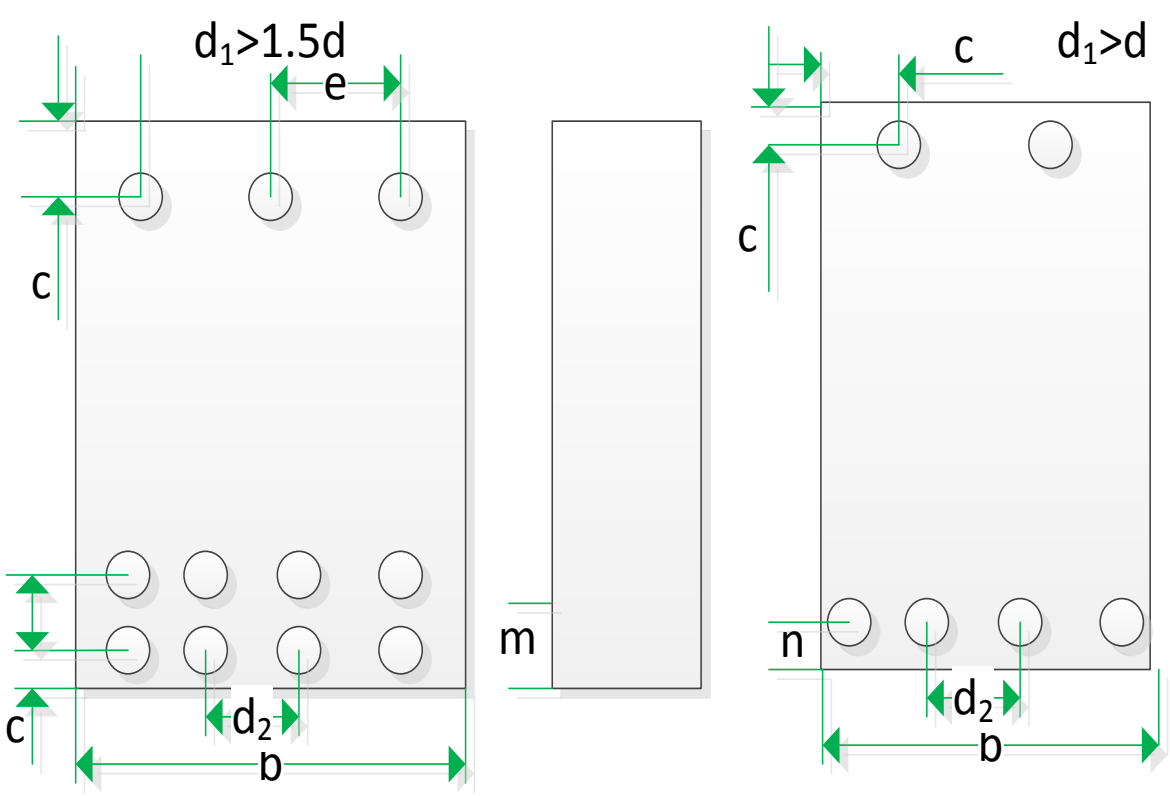

Figure 2. concrete cover

\section{Conclusion}

In a ward the durability of concrete structures in bridge, tunnel, road, port and other infrastructure projects has been a major problem that needs to be taken to deal with. Otherwise, the normal use of some projects and security were not be effectively guaranteed. China's modernization and the national economy will suffer huge losses, and it will give production and public life has long plagued. The bridge, tunnels, roads, ports and other infrastructure projects in the concrete structure durability, has been a major issue to be taken to address. It is urgent need to take measures. Otherwise, some works of normal use function and security will be not effective guarantee, the modernization of our country and the national economy will suffer great losses, and will give production and public life to bring long-term problems.

Recommended that the competent civil engineering design standard emphasis on the sector of the durability requirements when they reviewed it. A clear civil engineering design should have a minimum service life requirements, independent chapters and demonstration of the key project design. Document of civil engineering should have a normal life and durability design; Relevant departments can give key support on basic theory Research on the durability of concrete engineering projects in the next period, and in 
the near future compilation of relevant regulations and standards will be approvaled and funded.

The safety in the course of civil engineering, should be guaranteed by regular inspection and maintenance. For the important civil engineering, there is no need to carry out safety inspection regulations in China. On the basis of the investment in infrastructure projects : Attaches great importance to the new, light maintenance, is not conducive to ensuring the project life and investment efficiency. Recommended for the bridge, tunnel and other important public infrastructure and important public buildings, implementation safety testing of mandatory periodic in their use. To this end, it is need to develop regulations and the preparation of the corresponding technical standards; for the construction of civil engineering testing and assessment, it is also need to establish the registration system, qualification certification system and supervision system. Where the safety diagnosis of the construction of the project can also be classified into this industry. Suggestions on the construction of the relevant departments increase the proportion of engineering maintenance costs in the bridge, tunnel, road and other infrastructure projects, according to the need.

\section{REFERENCES}

[1] Y. Sieffert, J. M. Huygen, and D. Daudon, "Sustainable construction with repurposed materials in the context of a civil engineering-architecture collaboration," Journal of Cleaner Production, vol. 67, pp. 125-138, 2014.

[2] Augusti, G, Baratta, A., Casciati, F. Probabilistic Methods in Structural Engineering London, Chapman \& Hall, (1984)584 p. K. Elissa, "Title of paper if known," unpublished.

[3] Lind, N. Optimization, Cost Benefit Analysis, Specifications. Prob. 3rd Int. Conf. on Applications of statistics in Soil and Structural Engineering: (1979) Sydney, vol.3, pp. 373-384. M. Young, The Technical Writer's Handbook. Mill Valley, CA: University Science, 1989.
[4] Cretu, O., Stewart R.B., Berends T. Risk Management for Design and Construction (2011) USA, Wiley Pupl., 261 p.

[5] Smith, N.J., Merna, T., Jobling, P. Managing Risk in Construction Projects (2014) UK, Wiley Blackwell Publ., 239 p. Y. Yorozu, M. Hirano, K. Oka, and Y. Tagawa, "Electron spectroscopy studies on magneto-optical media and plastic substrate interface," IEEE Transl. J. Magn. Japan, vol. 2, pp. 740-741, August 1987 [Digests 9th Annual Conf. Magnetics Japan, p. 301, 1982].

[6] Melchakov, A.P, Bayburin, D.A., Kazakova, E.A. Konstrukcionnaya bezopasnost stroitelnogo obyekta: ocenka i obespechenie: uchebnoe posobie [Structural safety of construction object: evaluation and ensuring: guide] (2013) Chelyabinsk, South Ural State University Publ., 136p.

[7] Telichenko, V.I., Roytman, V. M. Osnovy kompleksnoy bezopasnosti stroitel'stva: monografiya [Fundamentals of complex safety of construction: monograph] (2011) Moscow, ABS, $167 \mathrm{p}$

[8] A. Ibrahimbegovic, Damage Assessment and Reconstruction after War or Natural Disaster. 2009. 7.

[9] Asokan, P., Osmani, M., Price, A.D.F., Assessing the recycling potential of glass fibre reinforced plastic waste in concrete and cement composites. [J]. Clean. Prod. 2009.17, 821e829.

[10] Melchakov, A.P., Bayburin, D.A., Shukutina, E.V. O bezopasnosti zastraivaemykh territoriy [About urban territories safety] Vestnik Yugno-Uralskogo Gosudarstvennogo Universiteta. Seriya «Stroitel'stvo i arkhitektura», (2014) no.14 (1), pp. 14-18.

[11] Lind, N. Optimization, Cost Benefit Analysis, Specifications. Prob. 3rd Int. Conf. on Applications of statistics in Soil and Structural Engineering: (1979) Sydney, vol.3, pp. 373-384. M Young, The Technical Writer's Handbook. Mill Valley, CA: University Science, 1989.

[12] Cretu, O., Stewart R.B., Berends T. Risk Management for Design and Construction USA, Wiley Pupl., 261 p.

[13] Smith, N.J. Managing Risk in Construction Projects (2014) UK, Wiley Blackwell Publ., 239 p. Y. Yorozu, M. Hirano, K. Oka, and Y. Tagawa, "Electron spectroscopy studies on magneto-optical media and plastic substrate interface," IEEE Transl. J. Magn. Japan, vol. 2. 